フルブリッジ型双方向 DC/DC コンバータの 2 次側短絡によるサージ電圧抑制

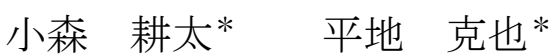

\title{
Surge voltage suppression by the secondary side short circuit for the full bridge type bidirectional DC/DC converter \\ Kota Komori*, Katuya Hirachi*
}

The full-bridge type bidirectional DC/DC converter is considered to be a promising topology for large capacity DC/DC conversion. Bidirectional DC/DC converter have two operation modes : Current-Mode and Voltage-Mode. It is well known that large surge voltage is generated at switching devices with current mode operation. The main factor of surge voltage is the leakage inductance of the transformer. The purpose of the study is the suppression of the surge voltage caused by the leakage inductance. In this paper we propose a novel control strategy which reduce the surge voltage of switching devices at current mode operation. Finally, experimental results of laboratory model which applied the new control strategy are presented, in which the reduction of surge voltage is realized.

キーワード : フルブリッジ型, 双方向 DC/DC コンバータ, サージ電圧

Keywords : Full Bridge Type, Bidirectional DC-DC Converter, Surge Voltage

\section{1. はじめに}

近年, 自動車や新エネの分野で双方向 DC/DC コンバータ が注目されている. 双方向 DC/DC コンバータでは一般に昇 圧する時は電流型動作, 降圧する時は電圧型動作を行うが, 電流型動作を行う際に大きなサージ電圧が発生することが 知られている(1) (7). サージ電圧の主な原因は変圧器の漏れ インダクタンスであると考えられる(2)(5). 本研究の目的 は，フルブリッジ型双方向 DC/DC コンバータにおいて漏れ インダクタンスに起因するサージ電圧を抑制することであ る. 新しい制御方式を提案し, 実験にて効果を確認したの で報告する。

2. フルブリッジ型+プッシュプル型双方向 DC/DC コンバータ

\section{$\langle 2 \cdot 1\rangle$ 主回路}

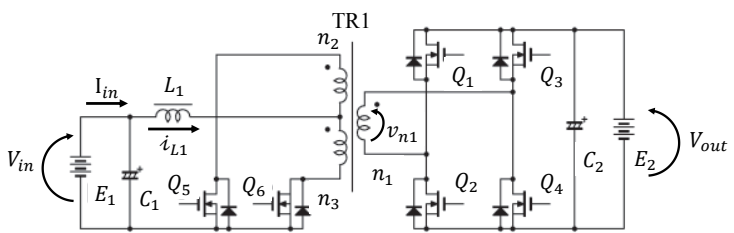

図1 フルブリッジ型+プッシュプル型双方向 DC/DC コンバータ

Fig.1 Full bridge type + push pull type bidirectional DC/DC converter

\footnotetext{
舞鶴工業高等専門学校

干625-8511 京都府舞鶴市字白屋 234 番地

Maizuru National College of Technology.,
}

234, Azashiroya, Maizuru-shi, Kyoto, 625-8511
フルブリッジ型双方向 DC/DC コンバータのうち電圧型フ ルブリッジ DC/DC コンバータと, 電流型プッシュプル DC/DC コンバータを組み合わせた回路を図 1 に示す。電圧 型動作を行う際は， $\mathrm{E}_{1}$ を負荷・ $\mathrm{E}_{2}$ を電源とし. 電流型動作 を行う際は， $\mathrm{E}_{1}$ を電源・ $\mathrm{E}_{2}$ を負荷とする.

\section{$\langle 2 \cdot 2\rangle \quad$ 従来の制御方式}

電流型プッシュプル DC/DC コンバータの従来の制御方式 のタイムチャートと波形を図 2 に示す.

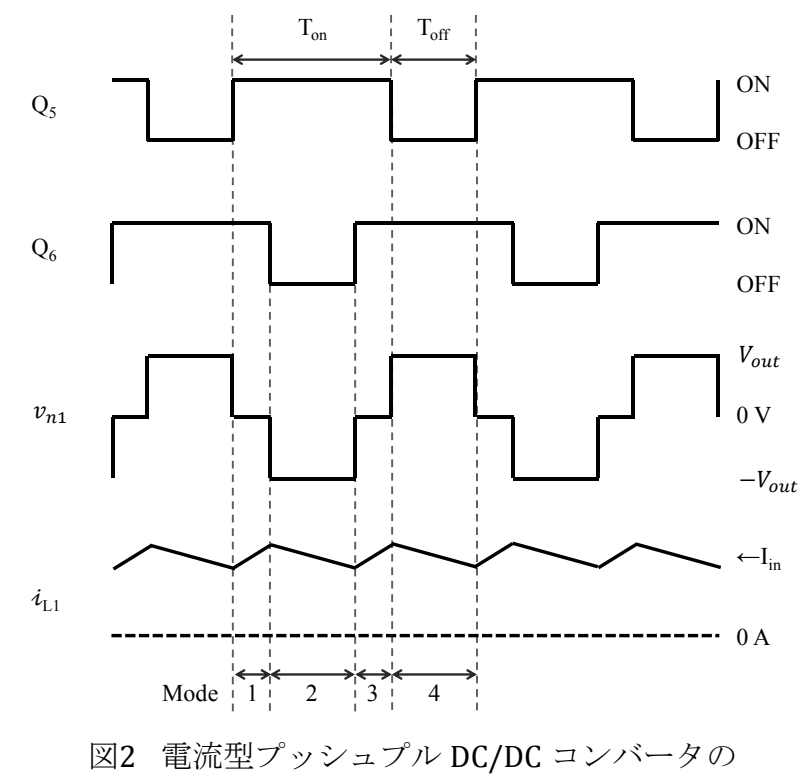

従来の制御方式

Fig.2 Conventional control strategy for current-mode push pull type DC/DC converter 
図 2 において，Mode1 及び Mode3 は，L L 1 にエネルギーを 蓄えるので, 蓄積モード. Mode2 及び Mode4 は, 2 次側に エネルギーを伝えるので伝達モードと呼ぶこととする. 一周期の内, 蓄積モードが占める割合を $\alpha$ と定義すると, 出力電圧 $V_{\text {out }}$ は次の式で表すことができる.

$$
V_{\text {out }}=V_{\text {in }} \frac{n 1}{n 2} \frac{1}{1-\alpha}
$$

従来の制御方式における各動作モードの電流経路を図 3 に示す.
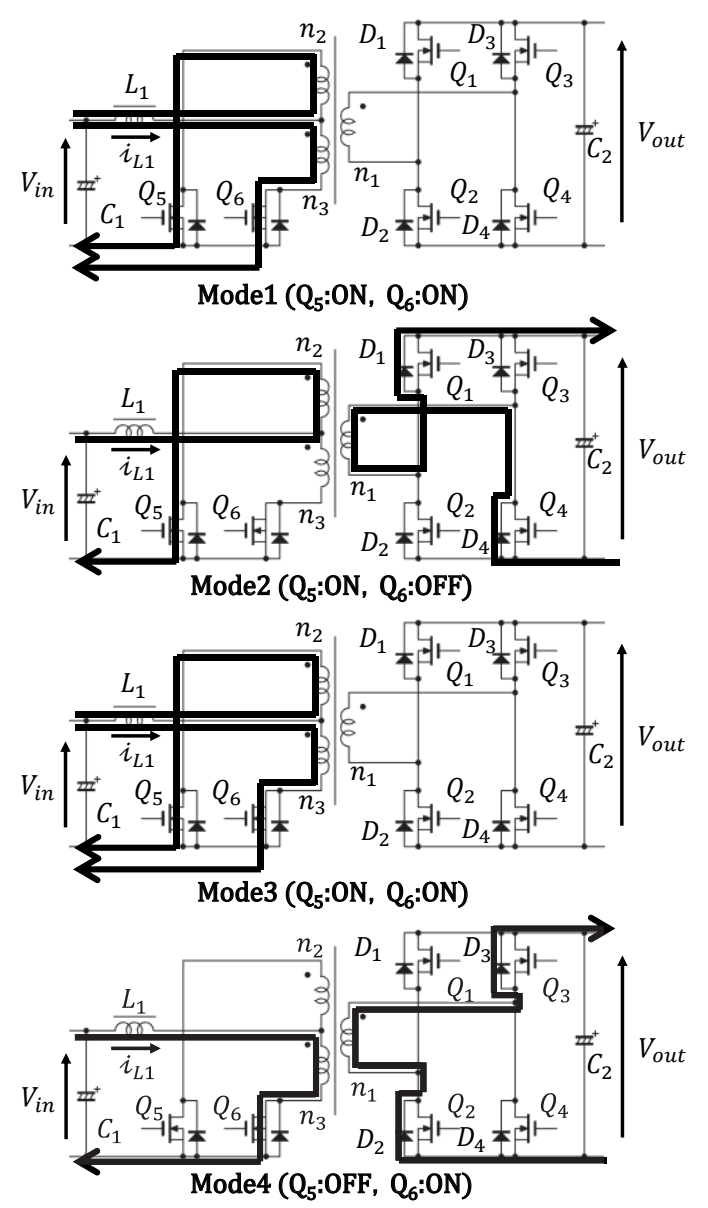

図3 従来の制御方式における電流経路

Fig.3 Current paths of conventional control strategy

Mode1 : 変圧器の一次コイルが短絡状態で, TR1の電圧は ゼロである. TR1 の $\mathrm{n}_{2}, \mathrm{n}_{3}$ が $\mathrm{Q}_{5}$ と $\mathrm{Q}_{6}$ で短絡された状態とな り, 電源電圧が印加され $\mathrm{L}_{1}$ の電流 $i_{\mathrm{L} 1}$ が直線的に増加する. Q6 がターンオフして Mode2 に移行する.

Mode2 : $\mathrm{L}_{1}$ が電流源として動作し, $\left.「 \mathrm{C}_{1} \rightarrow \mathrm{L}_{1} \rightarrow \mathrm{n}_{2} \rightarrow \mathrm{Q}_{5} \rightarrow \mathrm{C}_{1}\right\rfloor$ の経路で電流が流れる. この電流に対してトランスの 2 次 側に「 $\mathrm{C}_{2} \rightarrow \mathrm{Q}_{4}$ の寄生ダイオード $\mathrm{D}_{4} \rightarrow \mathrm{n}_{1} \rightarrow \mathrm{Q}_{1}$ の寄生ダイオー ド $\mathrm{D}_{1} \rightarrow \mathrm{C}_{2} 」$ の経路で電流が流れる. $i_{\mathrm{L} 1}$ は直線的に減少する. Q6がターンオンして Mode3 に移行する.

Mode3 : Mode1 と同じで, L $\mathrm{L}_{1}$ に電源電圧が印加され $\mathrm{L}_{\mathrm{L} 1}$ が 増加する. Q 5 がターンオフして Mode4 に移行する.

Mode4 : $\mathrm{L}_{1}$ が電流源として動作し, $\left.「 \mathrm{C}_{1} \rightarrow \mathrm{L}_{1} \rightarrow \mathrm{n}_{3} \rightarrow \mathrm{Q}_{6} \rightarrow \mathrm{C}_{1}\right\rfloor$ の経路で電流が流れる. この電流に対してトランスの 2 次
側に「 $\mathrm{C}_{2} \rightarrow \mathrm{Q}_{2}$ の寄生ダイオード $\mathrm{D}_{2} \rightarrow \mathrm{n}_{1} \rightarrow \mathrm{Q}_{3}$ の寄生ダイオー ド $\mathrm{D}_{3} \rightarrow \mathrm{C}_{2} 」$ の経路で電流が流れる. $i_{\mathrm{L} 1}$ は直線的に減少する. Q 5 がターンオンして Mode1 に移行する.

\section{$\langle 2 \cdot 3\rangle \quad$ 試作器の試験結果}

図 1 の回路を試作し，表 1 の条件で実験を行った。また 波形写真は周波数が $20[\mathrm{kHz}]$ ののである.

\section{表 1 実験条件}

Table 1. Experimental condition

\begin{tabular}{|c|c|c|}
\hline 入力電圧 & 出力電圧 & 出力電流 \\
\hline $24[\mathrm{~V}]$ & $48[\mathrm{~V}]$ & $2[\mathrm{~A}]$ \\
\hline$\alpha$ & \multicolumn{2}{|c|}{ 変圧器の巻数比 } \\
\hline 0.5 & \multicolumn{2}{|c|}{$\mathrm{n}_{1}: \mathrm{n}_{2}: \mathrm{n}_{3}=1: 1: 1$} \\
\hline
\end{tabular}

※ $\alpha$ は蓄積モードの割合

$\mathrm{Q}_{5}$ の $\boldsymbol{v}_{\mathrm{ds}}$ 波形（ $v_{\mathrm{ds}}$ は FET のドレインソース間電圧）を図 4 に変圧器の $\mathrm{n}_{1}$ 巻線電圧波形を図 5 にそれぞれ示す.

$2 \cdot 2$ 節で説明した従来の制御方式では，蓄積モードから 伝達モードに移行するときに，Q5 において非常に大きなサ ージ電圧が発生することが確認された。なお， $\mathrm{Q}_{5}, \mathrm{Q}_{6}$ にスナ バ回路は設けていない.

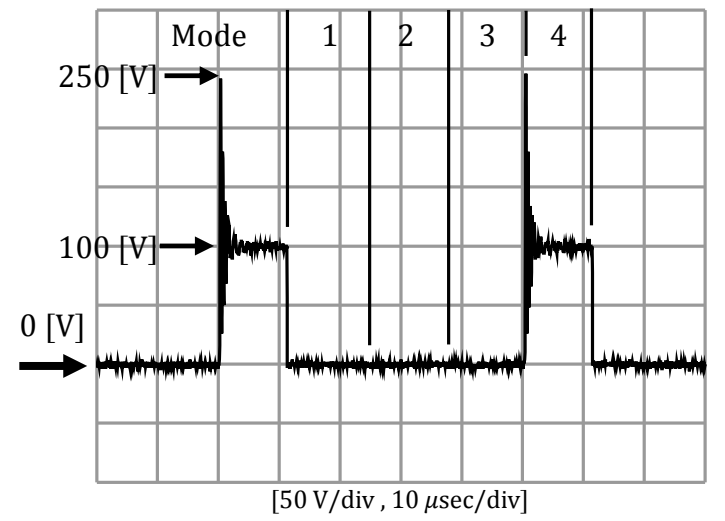

図4 $\mathrm{Q}_{5}$ の $v_{\mathrm{ds}}$ 波形

Fig.4 $v_{\mathrm{ds}}$ waveform of $\mathrm{Q}_{5}$

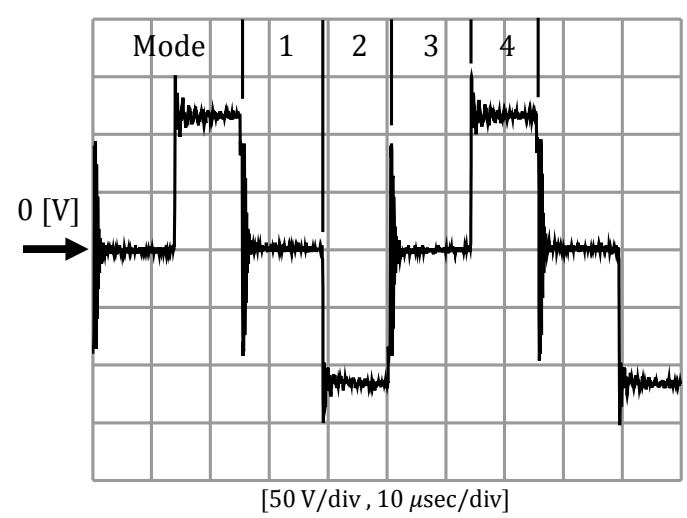

困5 変圧器の $\mathrm{n}_{1}$ 巻線電圧波形

Fig. $5 \mathrm{n}_{1}$ reel line voltage waveform of a transformer 図 4 より, Mode4 における $\mathrm{Q}_{5}$ の電圧は $100[\mathrm{~V}]$ 程度なのに 
対して, サージ電圧のピーク值はおよそ $250[\mathrm{~V}]$ と非常に大 きなものとなっていることがわかる. サージ電圧の原因に は, 回路におけるラインインダクタンスやトランスの漏れ インダクタンスなどが挙げられる. その中でも, 漏れイン ダクタンスに起因するサージ電圧が, 大きな割合を占めて いると考えられる.

\section{〈2・4〉 漏れインダクタンスに起因する サージ電圧の発生原理}

サージ電圧の発生原理を解明するために図 6 に示すよう に漏れインダクタンス $L \ell$ 及び $\mathrm{Q}_{5}, \mathrm{Q}_{6}$ の寄生容量 $\mathrm{C}_{5}, \mathrm{C}_{6}$ を考慮 する. 各動作モードについて説明を行う.

Mode1 : TR1 の $\mathrm{n}_{2}, \mathrm{n}_{3}$ が $\mathrm{Q}_{5}$ と $\mathrm{Q}_{6}$ で短絡された状態となり, 電源電圧が印加され $i_{11}$ が直線的に増加する.

この時, $i_{L 1}=i_{n 2}+i_{n 3}$ が成り立つ. $\mathrm{Q}_{6}$ がターンオフして Mode1-1 に移行する.

Mode1-1： $\mathrm{Q}_{6}$ がターンオフしたので， $\mathrm{Q}_{6}$ の寄生容量 $\mathrm{C}_{6}$ が充電される.この状態の等価回路を図 7 に示す． $\mathrm{E}_{1}, \mathrm{C}_{1}, \mathrm{~L}_{1}$ は定電流源 $i_{L 1}$ で置き換えている. $\mathrm{C}_{2}, \mathrm{VR}$ は定電圧源 $v_{\text {out }}$ で置 き換えている， $\mathrm{D}_{1}, \mathrm{D}_{4}$ は $\mathrm{Q}_{1}, \mathrm{Q}_{4}$ の寄生ダイオードである. この時, 次の式が成立する.

$$
\left\{\begin{array}{l}
i_{L 1}=i_{n 2}+i_{n 3} \\
v_{C 6}=v_{n 2}+v_{n 3}=2 v_{n 2} \\
v_{n 1}=\frac{n_{1}}{n_{2}} v_{n 2}=\frac{1}{2} \frac{n_{1}}{n_{2}} v_{C 6}
\end{array}\right.
$$

$v_{n 1}<V_{\text {out }}$ の時, 即ち $\frac{1}{2} \frac{n_{1}}{n_{2}} v_{C 6}<V_{\text {out }}$ の時は $\mathrm{D}_{1}, \mathrm{D}_{4}$ は逆バイ アスされており導通しない。 $v_{C 6}$ が $2 \frac{n_{2}}{n_{1}} V_{\text {out }}$ まで充電され ると $\mathrm{D}_{1}$ と $\mathrm{D}_{4}$ が導通し, 次のモードに移行する.

Mode1-2 : 前のモードで $\mathrm{C}_{6}$ が $2 \frac{n_{2}}{n_{1}} V_{\text {out }}$ まで充電されると $\mathrm{D}_{1}$ と $\mathrm{D}_{4}$ が順バイアスされて導通し, 2 次側に電流が流れは

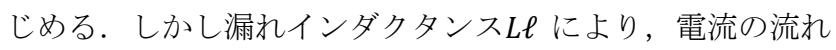
が妨げられる. そのため, 2 次側の電流はすぐには増加せず, 徐々に増加することになる。この状態の等価回路を図 8 に 示す， $\mathrm{D}_{1}, \mathrm{D}_{4}$ は順バイアスされ導通している. この時次の式 が成立する.

$$
\begin{aligned}
& i_{L 1}=i_{n 2}+i_{n 3} \\
& i_{n 2}-i_{n 3}=\frac{n_{1}}{n_{2}} i_{n 1} \\
& \text { よって } i_{L 1}-i_{n 3}-i_{n 3}=\frac{n_{1}}{n_{2}} i_{n 1} \\
& \text { 以上より } i_{n 3}=\frac{1}{2}\left(i_{L 1}-\frac{n_{1}}{n_{2}} i_{n 1}\right) \ldots \ldots \ldots \ldots . . . . . . \\
& v_{C 6}=v_{n 2}+v_{n 3}=2 v_{n 2} \\
& v_{n 1}=\frac{n_{1}}{n_{2}} v_{n 2} \\
& v_{L \ell}=v_{n 1}-V_{\text {out }} \\
& i_{n 1}=\frac{1}{L \ell} \int v_{L \ell} d t \\
& \text { よって, } i_{n 1}=\frac{1}{L \ell} \int\left(\frac{1}{2} \frac{n_{1}}{n_{2}} v_{C 6}-V_{\text {out }}\right) d t . . \\
& \text { ただし, } i_{n 1} \text { の初期値は } 0[\mathrm{~A}]
\end{aligned}
$$

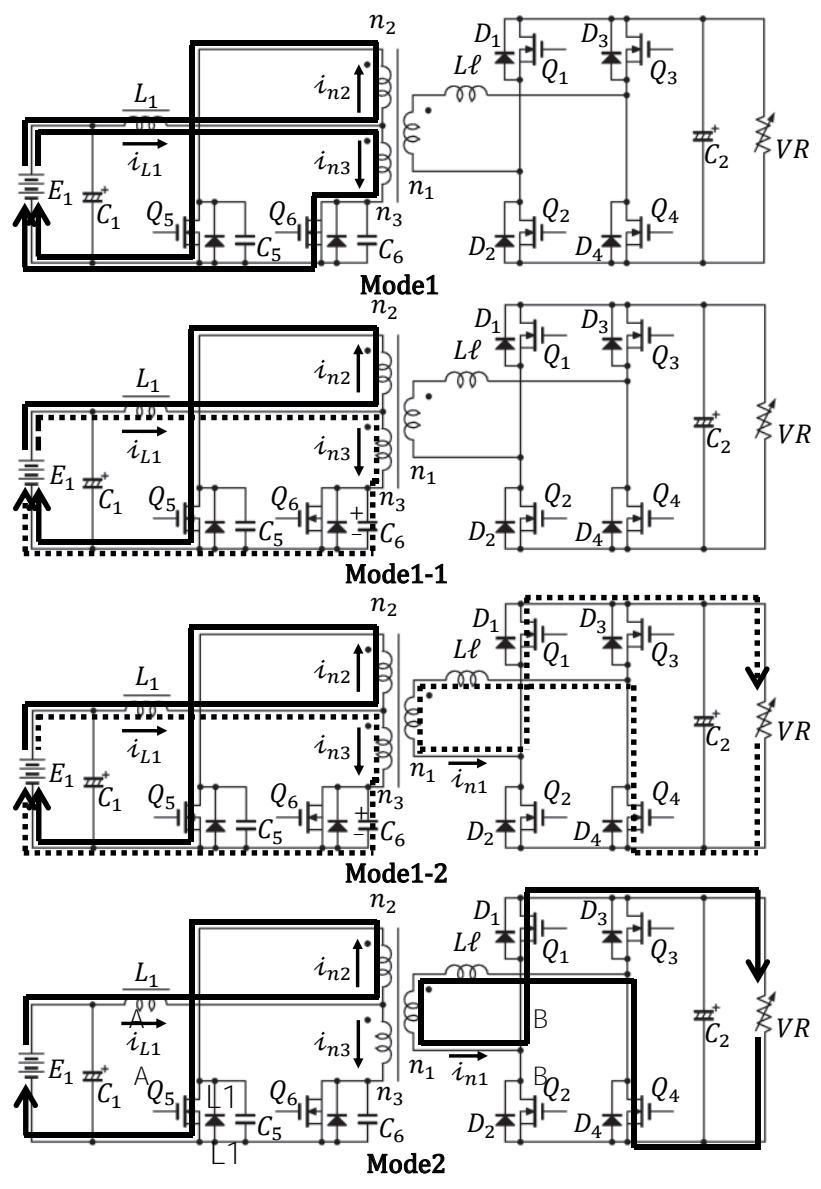

図6 漏れインダクタンスに起因するサージ電圧の発生原理 Fig. 6 Generation principle of a surge voltage due to the leakage inductance

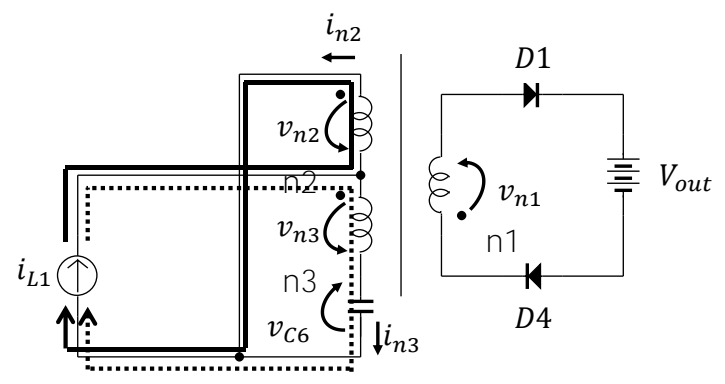

図7 従来の制御方式における等価回路(Mode1-1)

Fig.7 Equivalent circuit with conventional control strategy(Mode1-1)

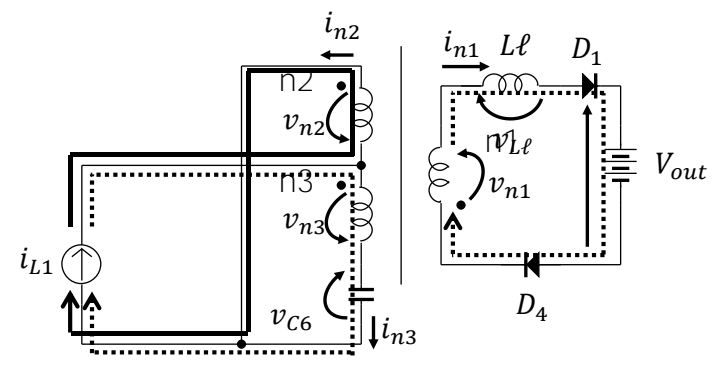

図8 従来の制御方式における等価回路(Mode1-2)

Fig.8 Equivalent circuit with conventional control strategy(Mode1-2) 


$$
v_{C 6}=\frac{1}{C_{6}} \int i_{n 3} d t
$$

ただし， $v_{C 6}$ の初期值は $2 \frac{n_{2}}{n_{1}} V_{\text {out }}$

(3)式から $i_{n 1}$ は徐々に増加することがわかる. (2)式から $i_{\mathrm{n} 1}$ の増加に伴い $i_{\mathrm{n} 3}$ は減少し, やがて $0[\mathrm{~A}]$ になることがわか る. $0[\mathrm{~A}]$ になった時点で $\mathrm{C}_{6}$ の充電は終了し Mode1-2 は終了 する. (4)式より Mode1-2 の間に $\mathrm{C}_{6}$ は高電圧に充電される. 即ち $\mathrm{Q}_{6}$ に大きなサージ電圧が発生することがわかる。 Mode1-2 の過渡状態が終了するとMode2 に移行する.

Mode2 : $\mathrm{L}_{1}$ が電流源として動作し, $\mathrm{E}_{1} \rightarrow \mathrm{L}_{1} \rightarrow \mathrm{n}_{2} \rightarrow \mathrm{Q}_{5} \rightarrow \mathrm{E}_{1}$ の 経路で電流が流れる. この電流に対してトランスの 2 次側 に $\mathrm{VR} \rightarrow \mathrm{Q}_{4} \rightarrow \mathrm{n}_{1} \rightarrow \mathrm{Q}_{1} \rightarrow \mathrm{VR}$ の経路で電流が流れる. $i_{\mathrm{L} 1}$ は直線的 に減少する。

\section{3. 従来のサージ電圧抑制方法}

2 章で説明したように双方向 DC/DC コンバータは, 電流 型動作時に大きなサージ電圧が発生する. その問題を解決 するために昨今では様々な提案がなされている，その一部 を図 9 と図 10 に示す.

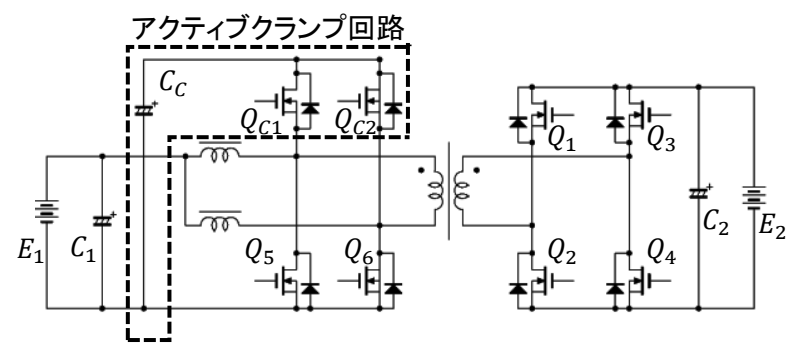

図9 従来のサージ抑制方式その $1^{(6)}$

Fig.9 Conventional surge suppression method No.1(6)

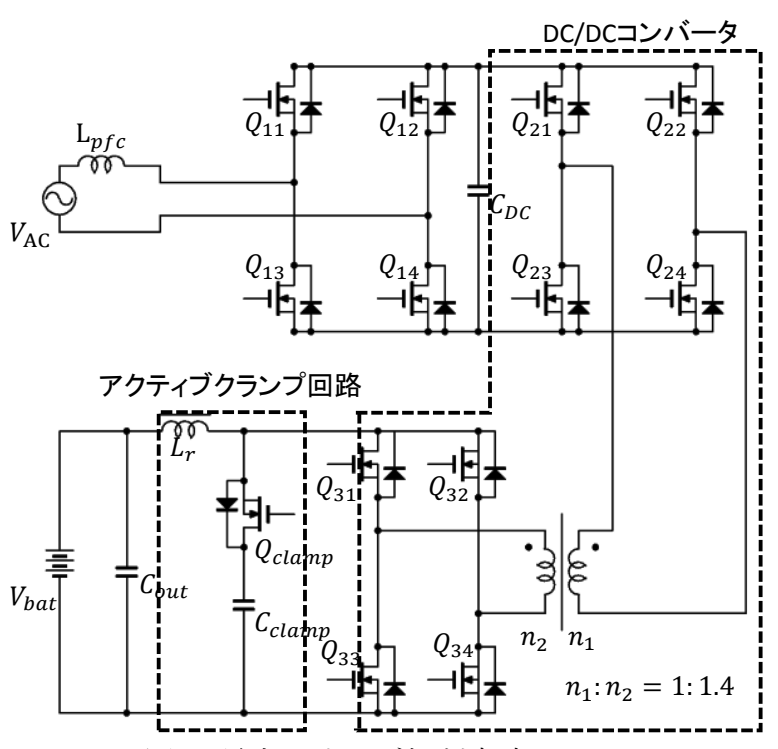

図10 従来のサージ抑制方式その 2(7)

Fig.10 Conventional surge suppression method No.2(7)
図 9 及び図 10 のアクティブクランプ回路付き双方向 DC/DC コンバータは，アクティブクランプ回路を動作させ ることで，サージ電圧をコンデンサに吸収し，クランプす ることでサージ電圧を抑制することができる，また，吸収 したエネルギーは伝達動作時に 2 次側に伝達することがで きるので損失を減らすこともできる(6)(7).

\section{4. 新しい制御方式の提案}

従来は, サージ電圧抑制のためにアクティブクランプ回 路などを追加することが必要だった，そこで回路の追加が なく制御方式の改善だけでサージ電圧を抑制する方法を提 案する.

〈4・1〉 タイムチャート

図 1 の回路において $\mathrm{Q}_{1} \sim \mathrm{Q}_{4}$ を位相シフト方式で動作させ る新しい制御方式を提案する. タイムチャートと主要な波 形を図 11 に示す。

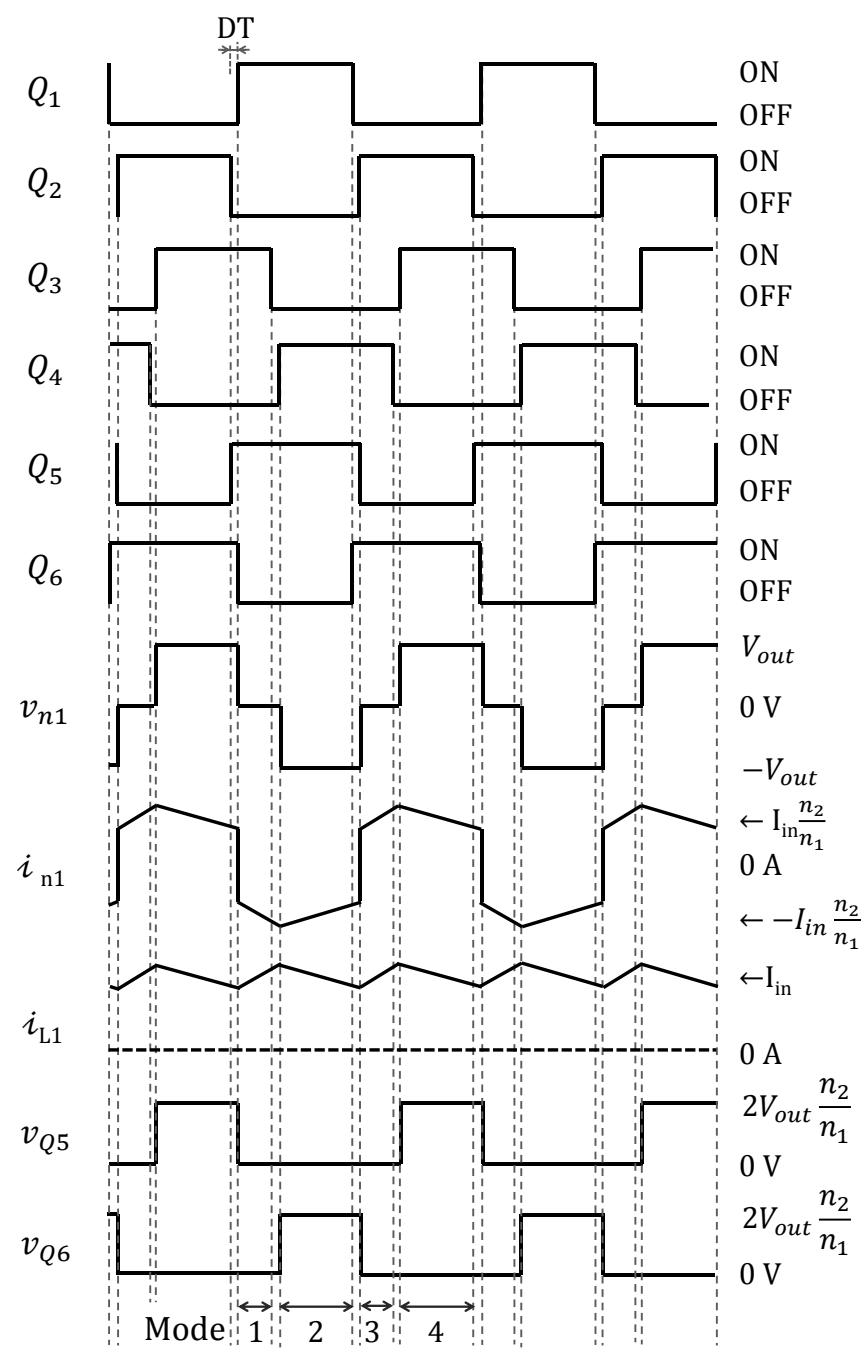

図11 提案する制御方式のタイムチャートと波形

Fig.11 Time chart and waveforms of proposed control strategy 
〈4·2〉ＤT(デッドタイム)について

新しい制御方式において $\mathrm{Q}_{1} \sim \mathrm{Q}_{4}$ で，上下の FET で同時 ON が起こらないようにデッドタイム(DT)を設けた。 また $\mathrm{Q}_{5}, \mathrm{Q}_{6}$ は重なり角を設けた。なお DT 及び重なり角は $750[\mathrm{nsec}]$ となるように調整した。 $\mathrm{Q}_{1}, \mathrm{Q}_{2}$ の $v_{\mathrm{GS}}$ 波形， $\mathrm{Q}_{5}, \mathrm{Q}_{6}$ の $v_{\mathrm{GS}}$ 波形を図 12 にそれぞれ示す.

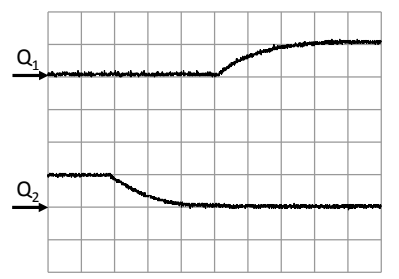

(a) $\mathrm{Q}_{1}, \mathrm{Q}_{2}$ の $v_{\mathrm{GS}}$ 波形

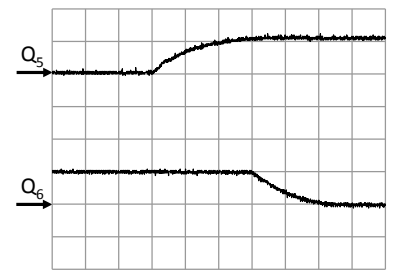

(b) $\mathrm{Q}_{5}, \mathrm{Q}_{6}$ の $v_{\mathrm{GS}}$ 波形
[10 V/div , $250 \mathrm{nsec} / \mathrm{div}$ ]

図12 FET のゲート電圧 $v_{\mathrm{GS}}$ 波形

Fig. 12 Waveform of $v_{\mathrm{GS}}$

\section{〈4·3〉 電流経路}

図 13 に新しい制御方式における電流経路を示す.
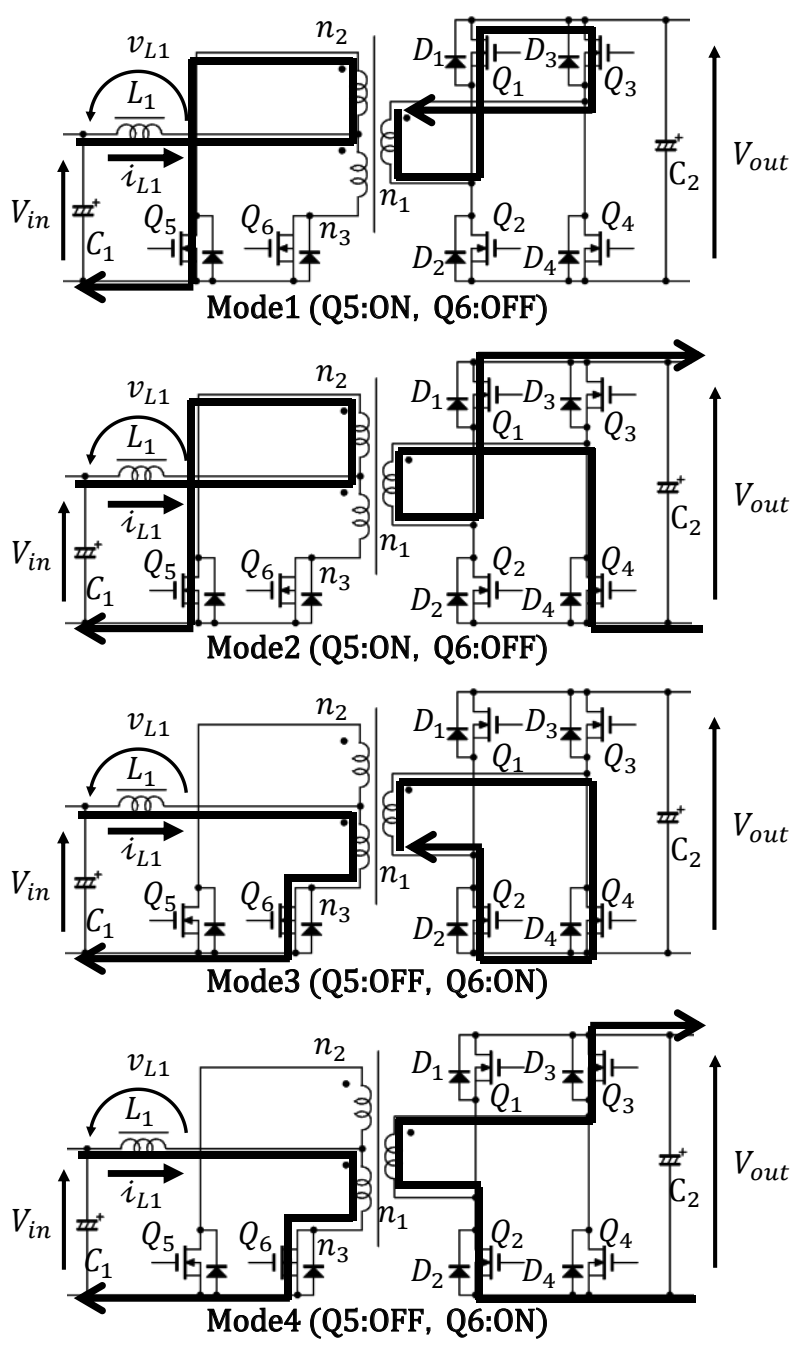

図13 新しい制御方式における電流経路

Fig.13 Current path of proposed strategy
図 13 の各動作モードについて説明する.

Mode1 : 変圧器の 2 次側コイルが $\mathrm{n}_{1} \rightarrow \mathrm{Q}_{1} \rightarrow \mathrm{Q}_{3} \rightarrow \mathrm{n}_{1}$ の経路で 短絡状態となり, 電源電圧が $\mathrm{L}_{1}$ に印加される. そのため, $v_{L 1}=v_{\text {in }}$ となり $\mathrm{L}_{1}$ の電流 $i_{\mathrm{L} 1}$ が直線的に増加する. $\mathrm{Q}_{3}$ が夕 ーンオフ・Q $\mathrm{Q}_{4}$ がターンオンして Mode2 に移行する.

Mode2 : 変圧器に流れる電流の方向は Mode3 の時と変わ らず, 2 次側は, $\mathrm{C}_{2} \rightarrow \mathrm{Q}_{4} \rightarrow \mathrm{n}_{1} \rightarrow \mathrm{Q}_{1} \rightarrow \mathrm{C}_{2}$ の経路で電流が流れる. $v_{L 1}=V_{\text {in }}-\frac{n 2}{n 1} V_{\text {out }}$ となり $v_{\mathrm{L} 1}$ が負となるので， $i_{\mathrm{L} 1}$ は直線的 に減少する. $\mathrm{Q}_{6}$ がターンオン・ $\mathrm{Q}_{1}$ がターンオフ・ $\mathrm{Q}_{2}$ がター ンオン・Q $\mathrm{Q}_{5}$ がターンオフして Mode3 に移行する.

Mode 3 : 変圧器の 2 次側コイルが $\mathrm{n}_{1} \rightarrow \mathrm{Q}_{4} \rightarrow \mathrm{Q}_{2} \rightarrow \mathrm{n}_{1}$ の経路で 短絡状態となり, 電源電圧が $\mathrm{L}_{1}$ に印加され $\mathrm{L}_{\mathrm{L} 1}$ が直線的に増 加する。 $\mathrm{Q}_{4}$ がターンオフ・Q $\mathrm{Q}_{3}$ がターンオンして Mode4 に移 行する。

Mode4:変圧器に流れる電流の方向は Mode3 の時と変わら ず, 2 次側は, $\mathrm{C}_{2} \rightarrow \mathrm{Q}_{2} \rightarrow \mathrm{n}_{1} \rightarrow \mathrm{Q}_{3} \rightarrow \mathrm{C}_{2}$ の経路で電流が流れる. $V_{\mathrm{L} 1}$ が負となるので， $i_{\mathrm{L} 1}$ は直線的に減少する， $\mathrm{Q}_{5}$ がターン オン・ $\mathrm{Q}_{2}$ がターンオフ・ $\mathrm{Q}_{1}$ がターンオン・ $\mathrm{Q}_{6}$ がターンオフ して Mode1に移行する.

図 3 と図 13 を比較すると, 従来の制御方式では図 3 の Mode1, Mode3 に示寸ように一次側で短絡し, 蓄積動作を行 っていたのに対し新しい制御方式では図 13 の Mode1,Mode3 に示すように 2 次側で短絡し, 蓄積動作を行っている.こ のため, 新しい制御方式は, 蓄積モードから伝達モードに 移行する際, 変圧器の電流方向が変化しない. このことか ら, 変圧器の漏れインダクタンスに起因する大きなサージ 電圧が抑制できると考えられる.

なお，Mode2 及び Mode4 は，従来の制御方式と新しい制 御方式とで, 電流経路は変わらない.

\section{$\langle 4 \cdot 4\rangle \quad$ 試作機の試験結果}

新しい制御方式の $\mathrm{Q}_{5}$ の $v_{\mathrm{ds}}$ 波形を図 14 に，新しい制御方 式による $v_{\mathrm{n} 1}$ 波形を図 15 にそれぞれ示す。試作器およびそ の動作条件は表 1 と同じである。なお， $Q_{5}, Q_{6}$ にスナバ回路 は設けていない.

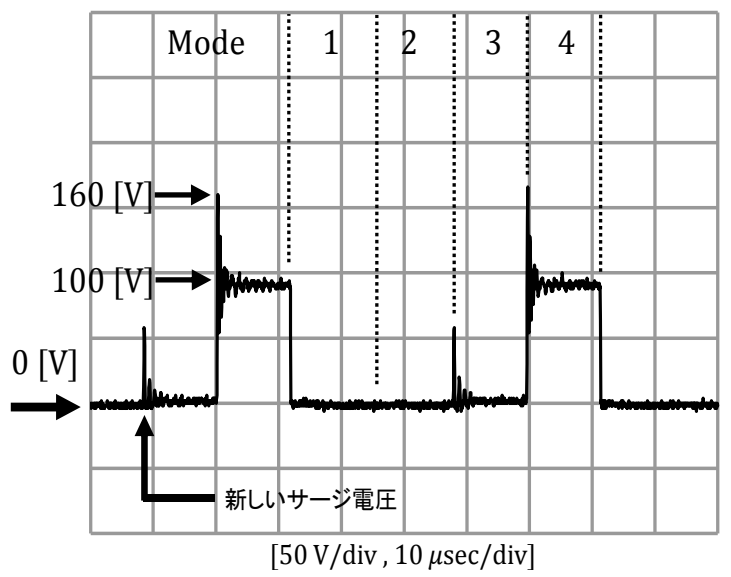

図14 Q 5 の $v_{\text {ds }}$ 波形

Fig.14 $v_{\text {ds }}$ waveform of $\mathrm{Q}_{5}$ 


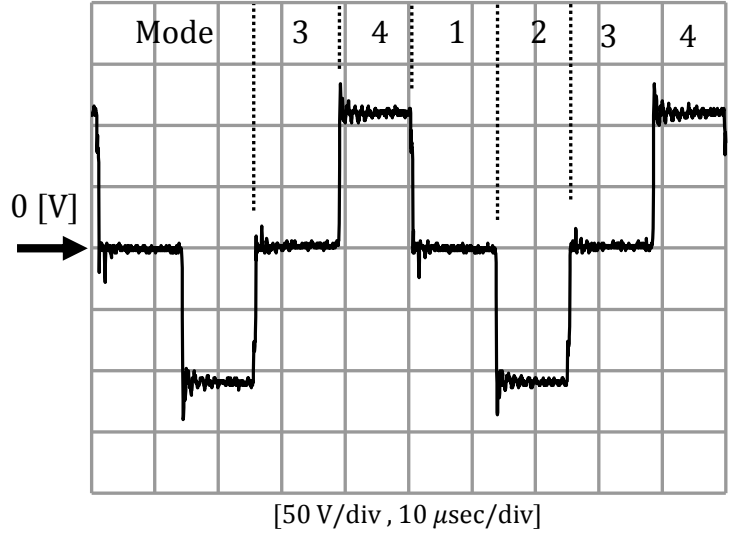

図15 変圧器の $\mathrm{n}_{1}$ 巻線電圧波形

Fig. $15 \mathrm{n}_{1}$ reel line voltage waveform of a transformer

図 4 と図 14 において, サージ電圧の大きさを比較すると, 蓄積モードから伝達モードに移行する際のサージ電圧を, およそ $90 \mathrm{~V}$ 抑制できていることがわかる，なお，伝達モー ドから蓄積モードに移行する際 $Q_{5}$ に新しいサージ電圧が発 生しているが, 值は小さい. 図 5 と図 15 を比較すると, 変 圧器のサージ電圧も新しい制御方式のほうが大幅に抑制で きていることがわかる.

\section{〈4·5〉 新しいサージ電圧について}

伝達モードから蓄積モードに移行する際に $Q_{5}$ に発生して いる新しいサージ電圧の発生原理を解明するために, 漏れ インダクタンス $L \ell$ 及び $\mathrm{Q}_{5}, \mathrm{Q}_{6}$ の寄生容量 $\mathrm{C}_{5}, \mathrm{C}_{6}$ を考慮する.

図 16 に新しいサージ電圧発生原理を示す。図 16 の各動 作モードについて説明する.

Mode4 : 2 次側は, $「 \mathrm{C}_{2} \rightarrow \mathrm{Q}_{2} \rightarrow \mathrm{n}_{1} \rightarrow \mathrm{Q}_{3} \rightarrow \mathrm{C}_{2} 」$ の経路で電流が 流れる. $v_{\mathrm{L} 1}$ が負となるので， $i_{\mathrm{L} 1}$ は直線的に減少する. $\mathrm{Q}_{2}$ がターンオフして Mode4-1に移行する.

Mode4-1 : $\mathrm{Q}_{2}$ がターンオフしたので 2 次側は, 「 $\mathrm{C}_{2} \rightarrow \mathrm{Q}_{2}$ の 寄生ダイオード $\mathrm{D}_{2} \rightarrow \mathrm{n}_{1} \rightarrow \mathrm{Q}_{3} \rightarrow \mathrm{C}_{2} 」$ の経路で電流が流れる. $\mathrm{Q}_{5}$ がターンオンして Mode4-2 に移行する.

Mode4-2：TR1 の $\mathrm{n}_{2} \mathrm{n}_{3}$ が $\mathrm{Q}_{5}$ と $\mathrm{Q}_{6}$ で短絡された状態とな り, 2 次側の電流が徐々に減少する. この状態の等価回路を 図 17 に示す. L $\ell$ には出力電圧 $V_{\text {out }}$ が電流を減少させる方 向に印加される. 2 次側の電流が $0[\mathrm{~A}]$ となって Mode4-3 に 移行する

Mode4-3 : 一次側のみ電流が流れている. Q6 がターンオフ して次のモードに移行する.

Mode4-4：Q6 がターンオフしたので， 2 次側は, 「 $\mathrm{n}_{1} \rightarrow \mathrm{Q}_{1}$ の寄生ダイオード $\mathrm{D}_{1} \rightarrow \mathrm{Q}_{3} \rightarrow \mathrm{n}_{1} 」$ の経路で電流が流れようとす る.しかし漏れインダクタンスにより, 電流の流れが妨げ られる，そのため， $i_{\mathrm{n} 1}$ 電流はすぐには増加せず， $\mathrm{Q}_{6}$ の寄生 容量 $\mathrm{C}_{6}$ が充電されるのと同時に, 徐々に増加することにな る. この状態の等価回路を図 18 に示す. 変圧器の 2 次側 $\mathrm{n}_{1}$ 巻線は $L \ell$ を介して短絡されている. この時次の式が成立 する.
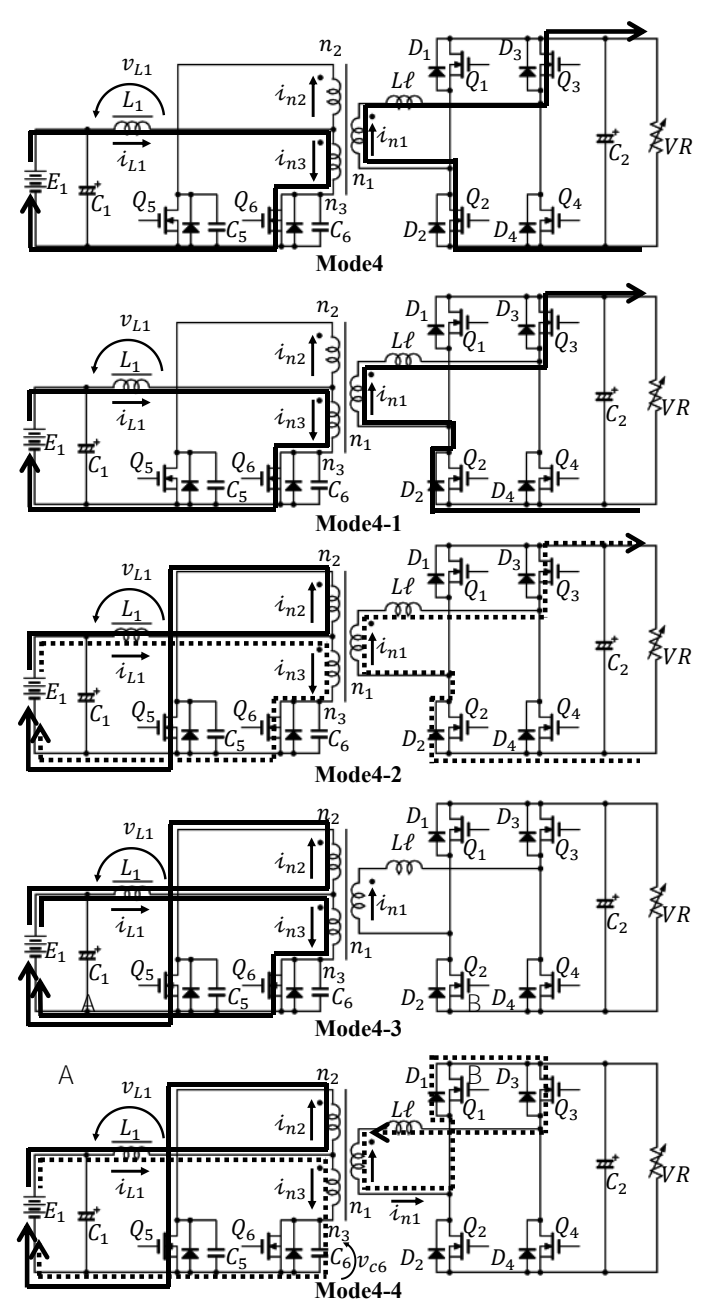

図16 新しいサージ電圧の発生原理

Fig.16 Generation principle of new surge voltage

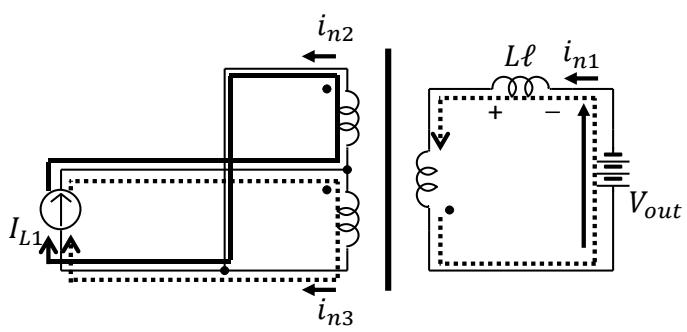

図17 提案する制御方式における等価回路(Mode4-2)

Fig.17 Equivalent circuit for proposed control strategy(Mode4-2)

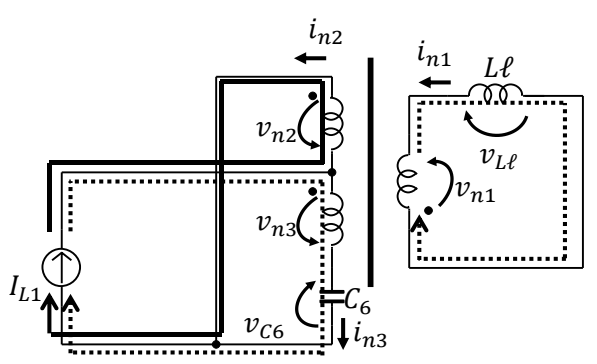

図18 提案する制御方式における等価回路(Mode4-4)

Fig.18 Equivalent circuit for proposed control strategy(Mode4-4) 
$i_{L 1}=i_{n 2}+i_{n 3}$

$i_{n 2}-i_{n 3}=\frac{n_{1}}{n_{2}} i_{n 1}$

よって $i_{n 3}=\frac{1}{2}\left(i_{L 1}-\frac{n_{1}}{n_{2}} i_{n 1}\right)$.

$v_{C 6}=v_{n 2}+v_{n 3}=2 v_{n 2}$

$v_{n 1}=\frac{n_{1}}{n_{2}} v_{n 2}$

$v_{L \ell}=v_{n 1}=\frac{n_{1}}{n_{2}} v_{n 2}=\frac{1}{2} v_{C 6}$

$i_{n 1}=\frac{1}{L \ell} \int v_{L \ell} d t=\frac{1}{L \ell} \int \frac{1}{2} v_{C 6} d t$

ただし $i_{n 1}$ の初期值は $0[\mathrm{~A}]$

$v_{C 6}=\frac{1}{C_{6}} \int i_{n 3} d t$

ただし $v_{C 6}$ の初期值は $0[\mathrm{~V}]$

(6)式から $i_{n 1}$ は徐々に増加することがわかる. (5)式から $i_{n 1}$ の増加に伴い $i_{n 3}$ は減少し, やがて $0[\mathrm{~A}]$ になることがわか る. $0[\mathrm{~A}]$ になった時点で $\mathrm{C}_{6}$ の充電は終了し Mode4-4 は終了 して通常の蓄積モード(mode1)に移行する。(7)式より Mode4-4 の間に $\mathrm{C}_{6}$ が充電される. 即ち $\mathrm{Q}_{6}$ に新しいサージ電 圧が発生することがわかる. 提案方式における Mode4-4 で のサージ電圧発生は変圧器の漏れインダクタンス $L \ell$ に起因 するものであり, 従来方式の Mode1-2 のサージ電圧発生に 似ている. しかし，提案方式では Mode4-4 では変圧器の 2 次側が短絡されており，また $\mathrm{C}_{6}$ の初期值が $0[\mathrm{~V}]$ なのでサー ジ電圧はあまり大きくならない.

\section{$\langle 4 \cdot 6\rangle$ 効率の比較}

試作機において, 従来の制御方式と新しい制御方式の 動作周波数を変更した際の効率の変化を図 19 に示す.こ の際, 両者で主回路は変えず制御方式のみ変更している.

図 19 より動作周波数の高い領域では新しい制御方式の方 が高効率となっている.

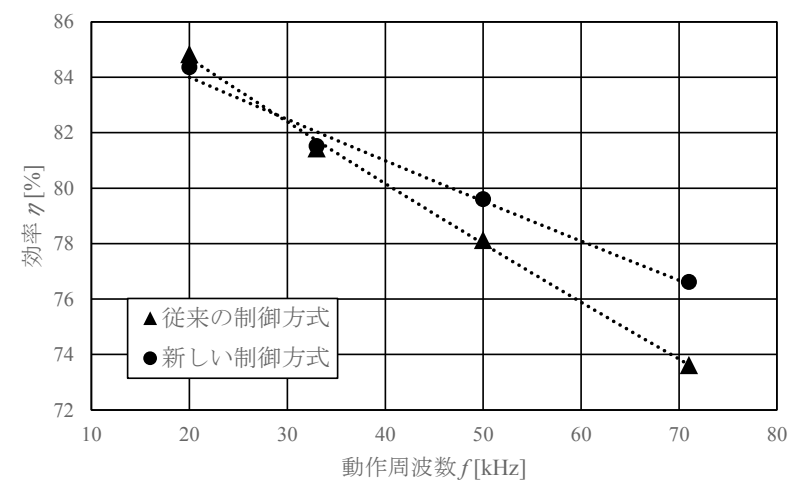

図19 周波数と効率の関係

Fig.19 Relationship between the frequency and efficiency

\section{5. おわりに}

電流型プッシュプル十電圧型フルブリッジ方式双方向 DC/DC コンバータにおいて, 新しい制御方式を提案した.
結果，新しい制御方式を用いるとスイッチ素子とトランス のサージ電圧を大幅に抑制できることを確認した。

新しい制御方式での蓄積モードから伝達モードに移行す る際に発生する漏れインダクタンスに起因するサージ電圧 はあまり大きくならないことを等価回路より確認した.

制御方式を変更するだけでサージ電圧の抑制が可能なの で，アクティブクランプ回路など特別なサージ抑制の回路 は不要である，そのため，小型化とコストダウンに有効で あると考えられる.

(2015 年 10 月 03 日発表)

\section{文献}

（1）吉富大祐・平地克也：「新しい昇圧フォワード型 DC/DC コンバータの 提案」, パワーエレクトロニクス学会誌, Vol.35, p.203 (2010)

（2）吉富大祐・伊藤淳一・平地克也：「絶縁型 DC/DC コンバータにおける 漏れインダクタンスとサージ電圧の関係について」, パワーエレクトロ ニクス学会誌, Vol.37, pp.68-80 (2012)

（3）吉富大祐・平地克也・藤原和也：「電流型 DC/DC コンバータにおける サージ電圧の抑制について」, 電気学会半導体変換研究会資料, SPC.11-40, pp.89-94 (2011)

（4）平地克也：「電流型プッシュプル方式 DC/DC コンバータ」, 平地研究室 技術メモ，No.20101227，http://hirachi.cocolog-nifty.com/kh/

(5) 吉富大祐:「電流型 DC/DC コンバータのスナバ回路設計方法について」, 平地研究室技術メモ, No.20110308, http://hirachi.cocolog-nifty.com/kh/

（6）大久保敏一・庄司浩幸・行武正剛：「クランプ回路付きプッシュプル 双方向絶縁型 DC-DC コンバータ」, 平成 21 年電気学会産業応用部門 大会, pp.679-680

（7） 大里康平・三浦友史・伊藤敏史：「アクティブクランプ回路を有する 昇圧動作可能な絶縁型双方向 DC-DC コンバータを用いた車載用双方向 充電回路」, パワーエレクトロニクス学会誌, Vol.40, p.195 (2015) 


\section{【質疑】}

$$
\text { (株)GS ユアサ・遠藤氏 }
$$

【質問 1】提案方式において 0[V]ラインにノイズ(新しい サージ電圧)がのっているが, 安定性への影響は? 放射伝導 ノイズへの影響は?

【回答 1】試作機は安定に動作している. 放射伝導ノイズ は未測定である.

【質問 2】高周波数帯域において提案方式が従来方式より も効率が良い理由は？また， ロス低減に対する定量評価 はどのようになっているか?

【回答 2】高周波数帯域において，提案方式が従来方式よ りも効率が良い理由は, 提案方式の方がスイッチング損失 が少ないからである．各部品の損失分析はできておらず, ロス低減に対する定量評価は今後の課題である.

株式会社 村田製作所・細谷氏

【質問 1】回路トポロジーとしては, センタータップ同期 整流方式を用いた双方向フルブリッジコンバータと同じと いう認識でよいか?

【回答 1】ご指摘の通りセンタータップ同期整流方式を用 いた双方向フルブリッジコンバータと同じである.

【質問 2】効率の測定において, 電力変換回路部分は同じ 測定回路を用いているか?

【回答 2】電力変換回路を変更せず制御回路のみを変更し て波形・効率の測定を行っている.

$$
\text { 神戸大学・三島氏 }
$$

【質問 1】 2 次側 MOS-FET の寄生容量はなぜ考慮しない のか? 技術的な理由はあるか?

【回答 1】 2 次側 MOS-FET の寄生容量の電荷は負荷に供 給されて損失にはならないと思われる. 1 次側 MOS-FET に 発生するサージ電圧には影響しないので本文中では考慮し ていない.
【質問 2】電力制御について, 周波数制御か位相シフト制 御のどちらを用いているか?

【回答 2】位相シフト制御を用いている.

株式会社 GS ユアサ・山口氏

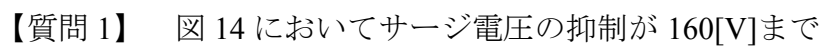
となっているが，完全に抑制できない理由は？

【回答 1】サージ電圧の要因となるのは漏れインダク タンスだけではなく, ラインインダクタンスも考えら れる.今回作製した主回路では FET から出力先までの 経路が長くなっており、ラインインダクタンスが大き くなってしまったことで、これに起因するサージ電圧 等が残っていると考えらる. 